\begin{tabular}{|c|c|c|c|c|c|c|}
\hline \multirow{4}{*}{ Impact Factor: } & ISRA (India) & $=3.117$ & SIS (USA) & $=0.912$ & ICV (Poland) & $=6.630$ \\
\hline & ISI (Dubai, UAE & $=0.829$ & РИНЦ (Russia & $=0.156$ & PIF (India) & $=1.940$ \\
\hline & GIF (Australia) & $=0.564$ & ESJI (KZ) & $=8.716$ & IBI (India) & $=4.260$ \\
\hline & JIF & $=1.500$ & SJIF (Morocco & $=5.667$ & OAJI (USA) & $=0.350$ \\
\hline
\end{tabular}

SOI: 1.1/TAS DOI: 10.15863/TAS
International Scientific Journal
Theoretical \& Applied Science
Y-ISSN: 2308-4944 (print) $\quad$ e-ISSN: 2409-0085 (online)
Yuar: $2019 \quad$ Issue: $06 \quad$ Volume: 74
http://T-Science.0rg

\title{
THE GIST OF DEVELOPING READING SKILLS ON PRIMARY SCHOOL PUPILS
}

\begin{abstract}
In this article, there are pedagogical-psychological data related to awakening love to books, forming reading skills, culture of reading books, rules of reading correctly, raising their awareness to literary books.

Key words: primary class, book, pupils, individual, reading skill, reading, speech, literary literature, education, literacy, technology, culture of reading.

Language: English

Citation: Muminova, D. A. (2019). The gist of developing reading skills on primary school pupils. ISJ Theoretical \& Applied Science, 06 (74), 482-485.

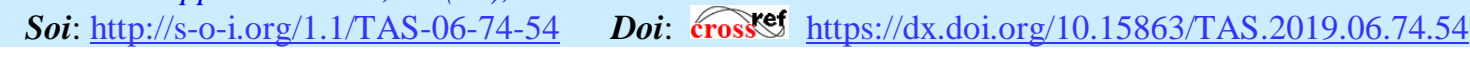

\section{Introduction}

It is advisable for primary school pupils to use books that promote their intellectual, psychological, and physiological development. Hence, through the reading of the book, students are encouraged to speak; speech (speech dictionary) is enriched; the image grows; thinking develops; memory toughens; feelings (sensual attributes, in particular, feeling of compassion) are brought up; "social perception" develops [3]. At the same time, it should be noted that the formation of "social perception" in a person maintains the ability to live. This confirms that achieving positive attitudes toward reading in primary school is one of the most important pedagogical tasks. By solving this task, starting from the elementary schooling period, the person (students) is gradually oriented towards social relations.

It is pedagogically correct to first define the difference between the concept of "skill" and "competence". "The ability to achieve the level of autonomy of skills training, if the skill is first of all conscious, is a barrier to the rapid advancement of the education sector."

\section{Materials and Methods}

The concept of "reading skills" can be defined as follows: reading skills - the ability of primary school pupils to learn the rules of reading, choosing a book (art work) based on their interests and needs, to be accustomed to reading a book, to consistently and constantly organize activities, to enjoy reading, to understand the essence of the work, and to share with others the impressions of the book.

Any progress will have a positive and negative impact on social development. In the time when the information technologies are developing rapidly the number of media that distribute information which satisfies the needs of individuals, and the growing scope of the way they have chosen, confirm that two aspects can be seen in the importance of the book and the reader: "The good point, increased demand for reading and transparency; It is a concern that massive readings are diminishing, and the number of meaningless books is increasing. "[5]

As mentioned earlier, literary books are useful for people of different ages, regardless of their age, they contribute to enrich speech, imagination and worldview, to expand their thinking, to develop their logical thinking skills, "to uplift their spirituality and abilities." [6]. In the global information environment, the creation of books that do not have a social, moral, or non-cultural value, even literary or even scientific literacy is not of high and practical value, urged people to develop their thinking ability, intelligence by making it as a social need. As a main factor for society members to gain their consciousness, thought, 


\begin{tabular}{|c|c|c|c|c|c|c|}
\hline \multirow{4}{*}{ Impact Factor: } & ISRA (India) & $=3.117$ & SIS (USA) & $=0.912$ & ICV (Poland) & $=6.630$ \\
\hline & ISI (Dubai, UAI & $=0.829$ & РИНЦ (Russia & $=0.156$ & PIF (India) & $=1.940$ \\
\hline & GIF (Australia) & $=0.564$ & ESJI (KZ) & $=8.716$ & IBI (India) & $=4.260$ \\
\hline & JIF & $=1.500$ & SJIF (Morocco & $=5.667$ & OAJI (USA) & $=0.350$ \\
\hline
\end{tabular}

and broader visibility it is vital that reading books is agitated among people.

According to Gudova's approach, the reading of the book should be studied in three cases: study, activity as a social institution and cultural practice [6, 15]. In our opinion, the book is a process of reading and a specific form of personal activity, and reading is based on the purposeful, consistent and effective organization of reading activities. In essence, processes and activities require organizational and methodological correct, rational and systematic organization. Accordingly, the development of the reading skills of primary school pupils should be systematic, consistent and structured according to the pedagogical and psychological requirements.

It is important to define the direction of the pedagogical activity of the primary school pupils, the basic concept of the problem of the development of reading skills, the basic concepts and to be aware of their content, and the precise representation of hypotheses will provide an opportunity to anticipate the expected result in advance. Therefore, attention is drawn to the separation of basic concepts that form the basis of the problem of scientific research and its pedagogical interpretation.

Today, children are often accused of not reading books. However, the need for them to offer a diverse range of literature is out of the reach of both teachers and librarians. To do this, teachers need to know students' interest in the books and their needs. One of the reasons why students do not read books is that parents cannot keep a family in love with the book, or a shortage of interesting, fascinating art books [14, 12].

Based on the theoretical analysis, it can be said that the development of reading skills in primary school pupils is carried out directly in five stages. (Figure 1.2.1):

The term "mutolaa" refers to the terms "read", "learn" when translated from the Arabic language. Theoretically, this concept is 'read, read and understand' $[9,655]$. It should not be forgotten that reading is a hard work for the elementary school students. According to V.A. Sukhomlinsky, "reading a book is like a way to help a smart, thinking educator to find a way to a child's heart." Walking along the path is not always easy. That is why it is desirable to gradually establish this process step-by-step.

The discrepancy between the time spent on reading book and the individual's psychological, physiological and physical abilities can lead to boredom and tiredness, which ultimately leads to a decrease in interest and demand. Therefore, in the process of reading the book, primary school teachers and parents should work on the psychological, physiological and physical capacity of the learners.

Pedagogical and psychological research has shown whether the individuals, in particular the pupils of the elementary school have skills and competences of reading, is measured by the following criteria: 1 . Reading correctly. 2. Fast Reading. 3. Coherence and cohesion of reading. 4 . Reading by understanding

Well, what do those notions mean?

If reading correctly does not break it out so that it does not affect what is being read, that is, reading it flawlessly [9,125], reading fast is a conscious perception of what is reading speed [9,134], understanding reading (consciousness, awareness), understanding the true content of the text read by the elementary school students, the idea, the images and the artistic means and the correct attitude towards the situation described by the author [9, 149-150].

In our opinion, reading by understanding is realizing the essence of the work, re-interpretation of the work, the actions of the heroes and the attitude towards the work.

The coherence and cohesion of reading is the essence of the work, which is formed in the process of analyzing the quality of the images.. The intonation is characterized by pausing in the speech, and the semiinterruptions, rhythm, accent, pitch, rising and falling [9, 119].

Reading a first-class book is determined by the educational and speech activity. The tutor continues to read a book to the children.

The second level of literary education is determined by the formation of initial images by studying the pictures as the basic method of working with books. A second-class book is based on learning and communicative activities (with the author or teacher, as well as the interaction of the students with each other), the impressions from the readings.

In the third and fourth grades, aesthetic reading (or aesthetic level) begins. Aesthetic level - is associated with the reader's understanding of the intellectual and emotional level of the artistic work.

What are highlighting in reading books? In other words, what qualities does the true reader possess? 


\begin{tabular}{|c|c|c|c|c|c|c|}
\hline \multirow{4}{*}{ Impact Factor: } & ISRA (India) & $=3.117$ & SIS (USA) & $=0.912$ & ICV (Poland) & $=6.630$ \\
\hline & ISI (Dubai, UAE & $=0.829$ & РИНЦ (Russia & $=0.156$ & PIF (India) & $=1.940$ \\
\hline & GIF (Australia) & $=0.564$ & ESJI (KZ) & $=8.716$ & IBI (India) & $=4.260$ \\
\hline & JIF & $=1.500$ & SJIF (Morocco & $=5.667$ & OAJI (USA) & $=0.350$ \\
\hline
\end{tabular}

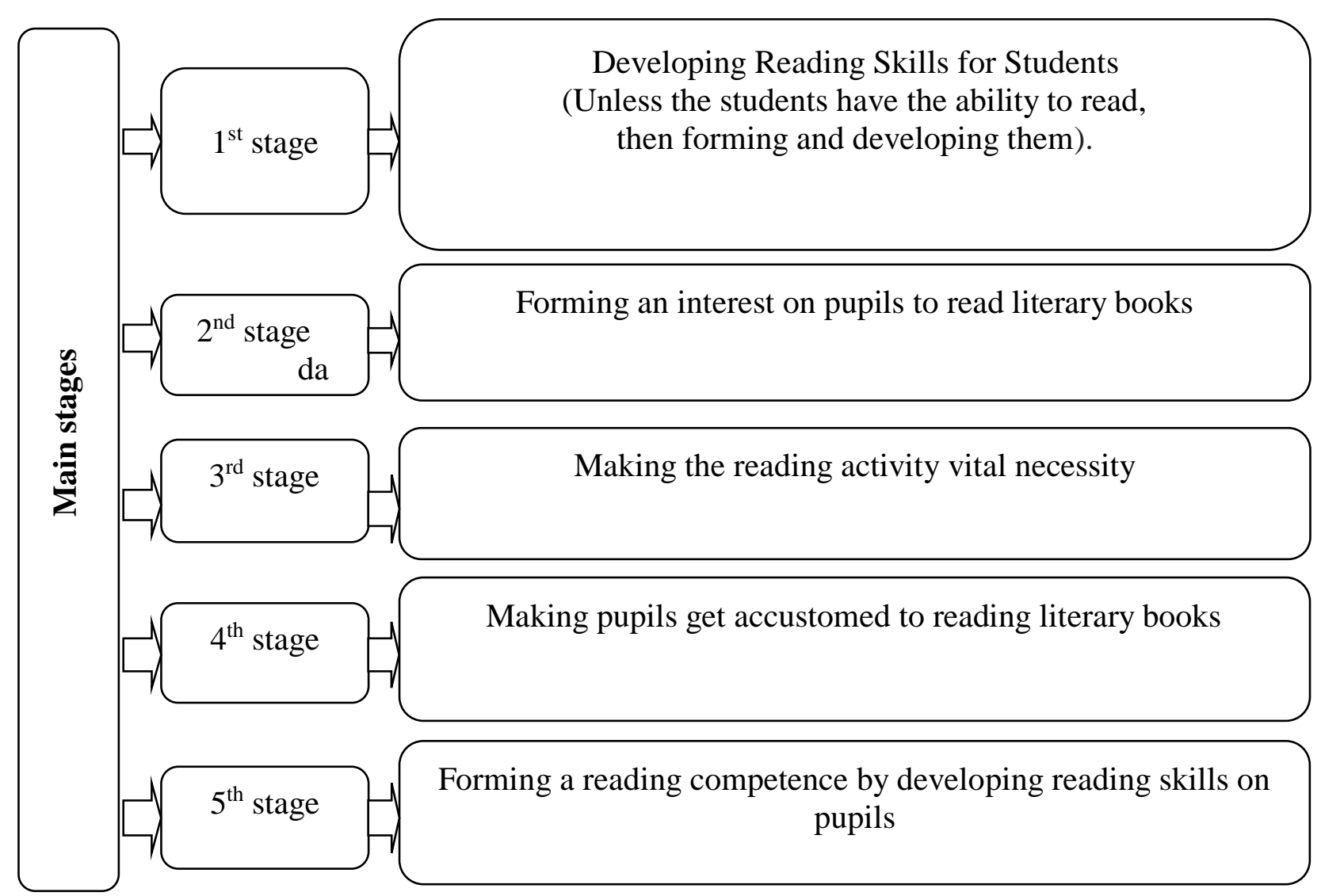

\subsection{1-figure. Main stages of development of reading skills on primary school students}

\section{Conclusion}

In the course of the research, it was found out that, as a result of life experience, pedagogical observation, and reading of books, including those of most readers of literary texts, readers have the following qualities: to understand the content of the work; to see a consistent linkage and interrelationship between the realities of the work; understanding the feelings, thoughts and aspirations of the heroes of the work, and expressing sympathy; putting himself in the place of the hero, trying to solve the problems that he has encountered, finding ways to solve the problem; to express personal attitude towards the content and reality of the work.

Among the books, children's books play an important role. This type of literature is also a source of personal development experience, which collects information on the environment like other types of books. This is why it is desirable for the elementary school pupils to have a positive attitude to the book as children's literature, not just a toy, but as an effective means of shaping their intellectual, emotional, and ethical culture. In fact, books and reading them have a special place in "raising the spirituality of the younger generation, the further development of our national literary and art, educating young people in the spirit of respect for our national values" [8].

Thus, the formation of reading skills for primary school pupils is a complicated pedagogical process. Its effective organization requires a primary, structured approach to this process from elementary school teachers. Therefore, elementary school teachers occupy leading positions in the formation of reading skills in respective age limits. The expected results can be achieved only if elementary school teachers are aware of the pedagogical-psychological basics and organizational-methodological requirements of the students in the process of reading skills. 


\begin{tabular}{llllll} 
& ISRA (India) $=\mathbf{3 . 1 1 7}$ & SIS (USA) & $=\mathbf{0 . 9 1 2}$ & ICV (Poland) & $=\mathbf{6 . 6 3 0}$ \\
Impact Factor: & ISI (Dubai, UAE) $=\mathbf{0 . 8 2 9}$ & PUHL (Russia) $=\mathbf{0 . 1 5 6}$ & PIF (India) & $=\mathbf{1 . 9 4 0}$ \\
& GIF (Australia) $=\mathbf{0 . 5 6 4}$ & ESJI (KZ) & $=\mathbf{8 . 7 1 6}$ & IBI (India) & $=\mathbf{4 . 2 6 0}$ \\
& JIF & $\mathbf{1 . 5 0 0}$ & SJIF (Morocco) $=\mathbf{5 . 6 6 7}$ & OAJI (USA) & $\mathbf{0 . 3 5 0}$ \\
\hline
\end{tabular}

\section{References:}

1. (2017). Y̌zbekiston Respublikasi Prezidentining "Kitob maxsulotlarini nashr etish va tarқatish tizimini rivozhlantirish, kitob mutolaasi va kitobkhonlik madaniyatini oshirish xamda tarғib қilish by̆yicha kompleks choratadbirlar dasturi ty̆ғrisida"gi (2017 yil 13 sentyabr') Karori. Retrieved 2019, from www.lex.uz/docs/3338600

2. Orlova, E. A. (n.d.). Rekomendatsii po povysheniyu urovnya chitatel'skoy kompetentsii $v$ ramkakh Natsional'noy programmy podderzhki $i$ razvitya chtenii. http://ifapcom.ru/files/publications/rekomend_o br_1.pdf

3. (n.d.). Osnovy chitatel'skoy kul'tury. Retrieved 2019, from https://studfiles.net/preview/6812001

4. (2018). Nima uchun kitoblarni ўқish tinglashdan yakhshiroқ? Retrieved 2019, from https://kun.uz/news/2018/10/16/nima-ucunkitoblarni-ukis-tinglasdan-yahsirok.

5. Khafizov, D. M. (2017). Sotsiokul'turnye praktiki povysheniya chitatel'skoy aktivnosti molodezhi: stimuliruyushchie vozmozhnosti mody: Avtoref.dis... kand.nauk. kul'turalogii. (p.27). Chelyabinsk.

6. (2007). Uzbek tilining izox̧li luzati. $N$-Tartibli / 5 zhildli. Uchinchi zhild. A.Madvaliev taxriri ostida. (p.416). Tashkent: Uzbekiston milliy entsiklopediyasi. Davlat ilmiy nashrieti.
7. Sukhomlinskiy, V. A. (2001). Serdtse otdayu detyam. (p.287). Minsk: Narodnaya asveta.

8. Sayyid, S. (2017). Kitobsiz kelazhak уўқ. Retrieved 2019, from http://uza.uz/oz/society/kitobsiz-kelazhak-y-16$\underline{01-2017}$

9. Leont'ev, A. N. (2009). Psikhologicheskie osnovy razvitiya rebenka i obucheniya. (pp.119185). Moscow: Smysl.

10. Umarov, A. (2003). Kitob va kitobkhon: an"analar va yangiliklar. Sozlom avlod uchun $\mathrm{zh}$, Tashkent, №11, pp.16-20.

11. Umarov, A. (2009). Kutubkhona - eshlar muloқо maskani // Betger ўқishlari - 2008: "Kutubkhona: eshlar tilida muloқоt" mavzusidagi davra suxbati mat.ty̆pl. (p.9-12). Taskent: A.Navoiy nomidagi Y̌zbekiston Milliy kutubkhonasi nashrieti.

12. Umarov, A. (2004). Kutubkhona faoliyati va mutolaa madaniyati. Zhamiyat va boshķaruv zh, Tashkent, №1, pp.14-18.

13. Umarov, A. (2004). Mutolaa madaniyati (kitob inson uchunmi eki inson kitob uchunmi?). Xaet va қ̧onun zh, Tashkent, №6, pp.74-76.

14. Kayumkhy̆zhaeva, E. (2007). Ўங̧uvchilarning kitobkhonlik madaniyatini shakllantirish imkoniyatlari. (p.12). Tashkent: A.Kodiriy nomidagi Toshkent davlat madaniyat instituti. 